\title{
Effect of Azolla as Feed Supplement on Milk Yield in Buffaloes
}

\author{
G.S. Meena ${ }^{1 *}$, B.L. Dhaka ${ }^{1}$, Bacchu Singh ${ }^{2}$, R.K. Meena ${ }^{2}$ and K.C. Meena ${ }^{3}$ \\ ${ }^{1}$ Krishi Vigyan Kendra, Bundi, India \\ ${ }^{2}$ Krishi Vigyan Kendra, Karauli, India \\ ${ }^{3}$ Krishi Vigyan Kendra, Swaimadhopur, India \\ *Corresponding author
}

\begin{tabular}{|c|c|}
\hline & A B S T R A C T \\
\hline $\begin{array}{l}\text { Ke y w o r d s } \\
\text { Azolla, Feed } \\
\text { Supplement, Milk } \\
\text { Production, } \\
\text { Buffaloes. }\end{array}$ & $\begin{array}{l}\text { Productivity of dairy animals largely depends on efficient feeding management. Balanced } \\
\text { and proper feeding results in better utilization of nutrients and optimum milk production. } \\
\text { Farmers feed their buffaloes with roughages and concentrate (cottonseed cake) without any } \\
\text { consideration about quality and quantity of feed in Bundi District of Rajasthan. Traditional } \\
\text { supplements based on cottonseed cake are expensive and cannot fulfill the required } \\
\text { nutrients to animals. There is ample scope for improving the productivity of livestock by }\end{array}$ \\
\hline Article Info & been reported as potential feed supplement for dairy animals, which have rich nutrient and \\
\hline $\begin{array}{l}\text { Accepted: } \\
\text { 26 October } 2017 \\
\text { Available Online: } \\
10 \text { December } 2017\end{array}$ & $\begin{array}{l}\text { mineral profile. An On Farm Trail was conducted to study the effect of Azolla as feed } \\
\text { supplement in buffaloes. The control group (C) farmers practice was fed wheat straw and } \\
\text { green fodder with cottonseed cake. In the treatment group (T) } 1.5 \mathrm{~kg} \text { fresh } \\
\text { azolla/animal/day was supplemented over conventional ration. The average daily milk } \\
\text { yield was significantly higher in treatment group. }\end{array}$ \\
\hline
\end{tabular}

\section{Introduction}

Livestock production is the backbone of the Indian economy and has been a source of employment in rural areas for centuries. Ruminants play a major role in providing nutritional and livelihood security for millions of rural households in India. Traditional supplement based on cottonseed cake is expensive and cannot fulfill the required nutrients to animals. Many researchers (Khutan and Ali, 1999; Satish and Ustuge, 2009 and Tamang and Samanta, 1993) have identified many unconventional feed and fodder to maintain the milk production particularly in off season. Azolla holds the promise of providing a sustainable feed for livestock.
Among many factors governing the livestock productivity, feeding accounts for more than $60-70 \%$ of the total recurring cost and hence qualitative and quantitative improvement in this aspect will usually improve productivity. There is acute shortage of feed and fodder for dairy animals due to lack of land availability for growing fodder for animals and high population density. The shortage of fodder is therefore, compensated with the use of readymade commercial feed resulting in increased cost of milk production. The search of alternatives to green fodder and concentrates led to a wonderful plant Azolla, which holds the promise of providing a sustainable feed for livestock. 
Azolla is a free floating, rapidly growing aquatic fern on water surface. It floats on the surface of water by means of numerous, small, closely overlapping scale-like leaves, with their roots hanging in the water. They form a symbiotic relationship with the cyanobacterium Anabaena azollae, which fixes atmospheric nitrogen, giving the plant access to this essential nutrient. Under ideal conditions it grows expotentially, doubling its biomass in every three days. It produces more than 4 to 5 times of protein of excellent quality in comparison to hybrid napier and lucern, respectively. Green plants have long been recognized as the cheapest and most abundant potential source of proteins because of their ability to synthesize amino acids from a wide range of virtually unlimited and readily available primary materials. Azolla is very rich in proteins, essential amino acids, vitamins (vitamin A, vitamin B12, Beta Carotene), growth promoter intermediaries and minerals including calcium, phosphorous, potassium, ferrous, copper, magnesium. Azolla has been reported as one of the most economic and efficient feed substitutes for livestock, particularly as can be easily digested by livestock due to its high protein and low lignin content. Azolla is called "Green Gold" due to these characteristics (Wagner, 1997).

Azolla has been used successfully as a protein supplement to dairy animals. According to Ambade et al., (2010), milk yield was increased by 15 to $20 \%$ after feeding azolla in the diet of dairy cows. Sanginga and Van Hove (1989) reported that the main character influencing the value of azolla as its feed is its amino acid composition.

The objective of the present study was to evaluate the use of Azolla meal as feed supplement in the diet of indigenous buffaloes in rural India, where animal keepers use only cottonseed cake as concentrate rations.

\section{Materials and Methods}

The present study was carried out in 2015-16 and 16-17 by establishing azolla production units in adopted villages of District Bundi, Rajasthan by Scientists of Krishi Vigyan Kendra Bundi. The livestock owners were proper trend by on and off campus practical training (Picture 1) on azolla production technology, according to Kamalasanana et al., (2002). Thereafter, a survey was conducted to assess the feeding, milk production and physical health status of animals in different villages where azolla production units were established and an On Farm Trail was conducted to study the effect of azolla on buffaloes milk yield in adopted villages Bagli, Neem Ka Khera, Hado Ka Pipalda and Ratabarda by Krishi Vigyan Kendra Bundi. For this purpose 20 lactating buffaloes of first to third lactation of 4 to 8 years old at mid lactation were selected for the study and randomly distributed into two groups of ten animals in each. The buffaloes were handmilked twice daily. Daily milk yield of each animal was recorded for a period of 2 months. The control $(C)$ group $(n=10)$ farmers practice was fed wheat straw, paddy straw and berseem with cottonseed cake. Whereas, the treatment $(\mathrm{T})$ group $(\mathrm{n}=10)$ was fed with same quantity of roughages and concentrate with supplementation of $1.5 \mathrm{Kg}$ fresh green azolla (azolla pinnata) (Picture 2). The feeding trial lasted for two months. During the trial daily milk yield were recorded and physical health status of animals were observed.

\section{Results and Discussion}

The present study was undertaken to know effect of feeding azolla on milk yield of lactating buffaloes under field conditions. The milk yield showed increasing trend and it increased to $9.30 \mathrm{~L} /$ day from $8.0 \mathrm{~L} /$ day after 60 days of feeding $1.5 \mathrm{Kg}$ azolla per day with conventional feed cottonseed cake. 
Picture.1 Azolla Demonstration Unit at KVK Bundi

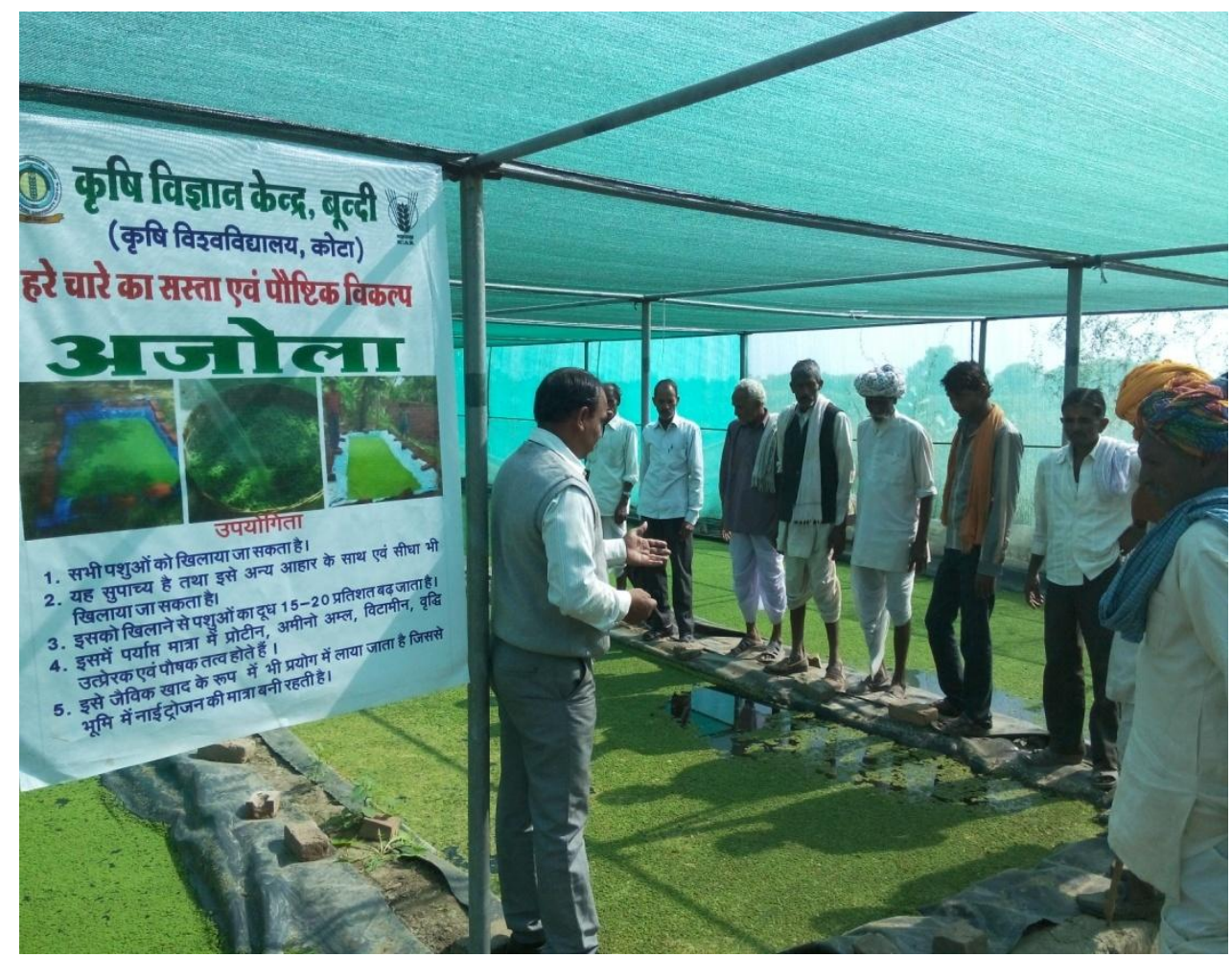

Picture.2 Feeding Azolla to Buffaloes






\section{Treatment details}

\begin{tabular}{|l|l|l|}
\hline S. No. & Treatments & $\begin{array}{l}\text { Milk Yield } \\
\text { (Lit./Day) }\end{array}$ \\
\hline $\mathbf{1}$ & $\begin{array}{l}\text { T1 = As per farmers' practice (Wheat straw, paddy straw, grass, } \\
\text { berseem and cotton seed cake) }\end{array}$ & $\mathbf{8 . 0}$ \\
\hline $\mathbf{2}$ & $\begin{array}{l}\text { T2= T1 + Deficiency of nutrients was fulfilled by providing green } \\
\text { azolla meal (1.5Kg/day/animal) }\end{array}$ & $\mathbf{9 . 3}$ \\
\hline $\mathbf{3}$ & Average Increase & $\mathbf{1 . 3}$ \\
\hline $\mathbf{4}$ & \% Increase & $\mathbf{1 6 . 2 5}$ \\
\hline
\end{tabular}

On an average milk yield increased by 1.30 L/day. About $16.25 \%$ increase in the milk yield is a tremendous improvement. It is in conformation with Singh et al., 2017, Mathur et al., (2013) and Kamalasanana et al., (2002) in buffaloes. Whereas, Kololgi et al., (2009) found $10 \%$ increase in milk yield in lactating buffaloes. Gouri et al., (2012), Ambade et al., (2010), Rawat et al., (2015) and Gowda et al., (2015) found similar results in cross bred cows. In contrast Murthy et al., (2013) found no significant difference among the groups with respect to milk yield in crossbred cows. Sanginga and Van Hove, (1989) reported that the main character influencing the value of azolla as its feed is its amino acid composition. In Various studies revealed that the azolla can be fed to these animals without any adverse effects. In this study, in azolla fed group has not only increased the milk yield but also increased in physical health status and reproductive efficiency. It is concluded that feeding fresh green azolla with cottonseed cake enhanced the milk production and the animal starts showing excellent sign of health, such as improved hair coat condition, shining in skin, brightness in eyes, moist muzzle and always activeness. Therefore, it can be used as a valuable green feed supplement for buffaloes, particularly under low input livestock production system, where livestock owners fed only cottonseed cake as concentrate or unbalanced concentrate ration, because the only single cake or unbalanced concentrate ration cannot fulfill the nutrient requirement of animal. Azolla can fulfill the requirement of nutrients of animal with cottonseed cake. Azolla is important for feeding to buffaloes for milk production and health. So we can produce more milk from indigenous buffaloes at low cost by feeding azolla with cottonseed cake.

\section{References}

Ambade R B, Jadhav S N and Phalke N B (2010). Impact of azolla as a protein supplement and its Influence on feed utilization in livestock. Livestock line. 4 (4): 21-23.

Gouri Mahadevappa D, Sanganal Jagadeesh S, Gopinath $\mathrm{CR}$, and Kalibavi CM (2012). Importance of azolla as a sustainable feed for livestock and poultry. Agric Review. 33 (2): 93-103.

Gowda NKS, Manegar A, Verma S, Valleesha NC, Maya G, Pal DT, Suresh KP (2015). Azolla (Azolla pinnata) as a Green Feed Supplement for Dairy Cattle-An On Farm Study. Anim Nutr \& Feed Tech, 15 (2): 283-287

Kamalasanana P, Premalatha S, and Rajamony S, (2002). Azolla - A sustainable feed substitute for livestock. Leisa India. March 2002, pp 15-17.

Khutan A, and Ali MA (1999). Comparision of nutritive value for laying hens of diets containing azolla (Azolla pinnata) based on formulation using digestible protein and digestible amino acid versus 
total protein and total amino acid. Anim Feed Sci Tech 81(1-2): 43-56.

Kololgi SD, Hosamani SV, Malshet Karuna and Nagraj MS (2009). Azolla an organic feed supplement feed for livestock. National symposium on Organix Livestock Farming- Globle issue, trends and challenges, 26-28 Feb, Kolkata, pp. 35.

Mathur GN, Sharma Ramakant and Choudhary PC (2013). Use of Azolla (Azolla pinnata) as Cattle Feed Supplement. J. Krishi Vigyan 2 (1): 7375.

Murthy TNK, Ashok M, Thirumalesh T, Umesh BU, Nataraju OR (2013). Effect of partial replacement of Azolla for concentrate supplement on lactating crossbred cows. J Env Ecol 31 (2): 415417.

Rawat Nidhi, Kumari K, Singh F, Gilhare VR (2015). Effect of Azolla-supplemented feeding on milk production of cattle and production performance of broilers. Applied Biological Research 17 (2): (214- 218).

Sanginga N and Van Hove C (1989). Aminoacid composition of azolla as affected by strain and population density. J Plant and Soil. 117 (2): 263267.

Satish B and Ustuge SM (2009). Azolla production and livestock feeding. National symposium on Organix Livestock Farming- Globle issue, trends and challenges, 26-28 Feb, Kolkata, pp21.

Singh Bacchu, Meena G. S, Meena K. C, Meena R. K, Singh Bachchu and Indoria Deepa (2017). Effect of a Wonder herb Azolla on Buffaloes Milk Yield. Int. J. Curr. Microbiol. App. Sci 6 (11): 1-8

Tamang Y and Samanta G (1993). Feeding value of azolla (Azolla pinnata) an aquatic fern in Black Bengal goats. Indian J Anim Sci 63 (2): 188-191.

VK-NARDEP (2010). Azolla Backyard cultivation: Innovation and ecological significance. http://vknardep.org/ services/sustainable-agriculture/81azolla-for-the-rescue.html.

Wagner GM (1997). Azolla: A review of its biology and utilization. Botani Review 63 (1): 1-26.

\section{How to cite this article:}

Meena, G.S., B.L. Dhaka, Bacchu Singh, R.K. Meena and Meena, K.C. 2017. Effect of Azolla as Feed Supplement on Milk Yield in Buffaloes. Int.J.Curr.Microbiol.App.Sci. 6(12): 34903494. doi: https://doi.org/10.20546/ijcmas.2017.612.406 